\section{Psychiatry in Britain one hundred years ago}

\author{
HENRY R. ROLLIN
}

In early 1985 , in the course of conversation, Hugh Freeman (then Editor of the British Journal of Psychiatry) casually threw out the suggestion that I might write a column for the journal similar to one entitled 'One Hundred Years Ago', occasionally published in the BMJ. I was immediately intrigued and, despite a degree of apprehension, agreed on the spot. Once I began, the element of apprehension evaporated: a job that I feared I might have found a crashing bore became a labour of love. Suitable items, I discovered, were there in plenty so that the problem soon became one of exclusion rather than inclusion. The journals systematically trawled, dating from 1885 onwards, were the $B M J$, the Lancet, the Journal of Mental Science (the forerunner of the British Journal of Psychiatry), the American Journal of Psychiatry and occasionally the daily press. The first selected item was published in April 1985, and with one exception an item has appeared in every subsequent issue, now more than 250 in total. What I have attempted to do in this article is to collate a selected number of these items and to categorise them so that they present a composite of snapshots of the passing scene as it impinged on aspects of psychiatry and psychiatrists (alienists) at the turn of the previous century.

No period in history can be considered in isolation: history is a continuum, and any period must be seen in relation to what came before. In other words, what follows later must be seen in the context of the events of at least the previous half-century. Psychiatry at the time we are considering relates almost exclusively to what was available to patients in the public county asylums in Britain together with the few patients remaining in private madhouses, and their staff, medical and nursing. The county asylums built from the mid-19th century onwards were the result of intense political pressure exercised by powerful, well-meaning reformers of the calibre of the 7th Earl of Shaftesbury (1801-1885).
(There is a poignant entry in Lord Shaftesbury's diary which expresses the plight of these unfortunates: it reads, 'Madness constitutes a right as it were, to treat people as vermin' (Scull, 1989).) These eminent reformers had a vision: they saw the long-suffering 'pauper lunatics' (the pejorative name used in Victorian times) transported into patients' palaces set in Elysian fields. The patients must be well-fed, warm and comfortable. Furthermore, these new 'palaces' must be limited in size and house no more than 300 patients. What was at the core of these starry aspirations was the belief that the dramatically improved environment the patients would enjoy was enough per se to bring about a cure for whatever ailed them.

However, the grand design of the reformers was frustrated by the sheer weight of economic, social and ecological upheavals then erupting, particularly industrialisation and concomitant urbanisation bringing in its train an unparalleled increase in the birth rate. For example, during the reign of George III (the period 1760-1820) the population of England and Wales rose from 7 million to 12 million, and the steep rise continued so that by 1890 the population had reached nearly 30 million. Pari passu, the number officially identified as insane had risen to over 86000 (Scull, 1982); the result was that the existing facilities for people with mental illness were overwhelmed and the hapless patients were the victims. The irony was, therefore, that the dream mansions created by the reformers were barred precisely to those for whom they were established. Instead, the unfortunates were forced into workhouses, bridewells and, even more tragically, gaols. Not surprisingly, there was a public outcry: more lunatic asylums must be built. And they were - in plenty. Many of them were built during the period under discussion and were still in existence until recently when the charismatic catchphrase 'community care' was transformed into a reality.
The newly built asylums, however, were travesties of those dreamed up by the early reformers: they were huge, housing 2000 and more patients; they were crowded, uncomfortable and therapeutically stagnant. They had become, in effect, society's dustbins. The patients the staff had to deal with (they had no choice as to who was to be admitted) were, in addition to bona fide patients, an assorted rag-bag of social misfits: people with varying grades of learning disability; those addicted to drugs and alcohol, either acutely or chronically disturbed; those with personality disorders of protean varieties; vagrants; the aged who had become an embarrassment to their kin; pregnant single women who had been cast out by their relatives; and anyone who by hook - and not infrequently by crook - could be squeezed into whatever the law required to be 'certified'. Voluntary admission was not an option. Further evidence emerges from a graphic description of conditions in Colney Hatch Hospital in 1851:

'No sooner had the asylum filled up than a queue
began to form of patients awaiting admission
which stretched into the 20th century. They were
numbered in hundreds. Most of them lingered in
workhouses which had no facilities or in licenced
houses which were expensive. Those were the
very evils county asylums were designed to
remove' (Hunter \& MacAlpine, 1974).

Worse was still to come. The rosy optimism of the reformers and of the medical staff turned into bitter pessimism as they saw their already crowded hospitals choked with patients who were chronically insane. The improved environment had proved to be no more than a palliative; mental illness for a substantial number remained stubbornly incurable. So, for whatever reason, the asylum population had spiralled as described. It is not surprising, therefore, that the resulting appalling chaos merited the acid comment: 'a gigantic asylum is a gigantic evil and, figuratively speaking, a manufactory of chronic insanity' (Arlidge, 1859).

\section{THE ARGUMENT}

In shuffling the items to be included in this paper, I found that they fell conveniently into relatively few, but not necessarily mutually exclusive, categories:

(a) overcrowding in asylums

(b) classification of lunatics

(c) professional status of psychiatry 
(d) staffing and training in mental asylums

(e) diagnoses

(f) treatment

(g) the management of lunacy in general

(h) doctors $v$. lawyers

(i) the Medico-Psychological Association (MPA).

\section{Overcrowding in asylums}

Because of their chaotic policy (or nonpolicy) of admissions, asylums had deteriorated into overcrowded, closed institutions, half workhouse and half prison. It is not surprising, therefore, that relevant problems are dominant in the selection of items. Pleas for a solution were made from asylums all over Britain. For instance, in Ireland (Journal of Mental Science, February 1882), reference is made to Maryborough Asylum where the 'asylum buildings were so overcrowded that he [the medical superintendent] had to place his patients under canvas'. Because of the numbers of patients inappropriately admitted and the consequent overcrowding, protests were inevitable. One (Lancet, 17 August 1895) refers to a report of the Lunacy Commissioners in which it states that the Commissioners 'have consistently expressed their opinion that the large numbers of known lunatics is mainly due to causes other than an increase in the prevalence of insanity as an active disease'. It goes on to refer to an analysis of the ages of the patients admitted and claims that there is 'conclusive proof that the cases admitted above the age of 60 years have increased at a far more rapid rate than the admissions under that age. These cases represent, probably, to large extent, transfers from workhouse to asylums'.

A further example of the gross abuse of the purpose of lunatic asylums is evidenced from the Royal Lunatic Asylum, Montrose (Lancet, 3 July 1897): in his report $\mathrm{Dr}$ Howden complains that 'many of the patients [are] admitted in a dying condition' and he suggests that 'a medical man is required to certify that a patient is in a sufficiently good state of health to be removed to the asylum'.

Yet another example of the abuse of certification, reported by $\mathrm{Dr}$ E. Goodall (Lancet, 3 October 1900), is of a girl who is a source of great trouble at home, but is neither mad enough to be in an asylum, not bad enough to be in gaol and probably best suited for a reformatory'.
In Scotland too (BMJ, February 1896) there is talk of problems at the Royal Edinburgh Asylum resulting from the class-ridden society prevailing at that time:

'Dr Clouston hoped the negotiations now in progress would lead to a diminution of the overcrowding of the rate-paid wards, and consequently to their difficulty in admitting the poorer private patients who applied for admission.'

Again in Edinburgh (Journal of Mental Science, July 1897), there is reference to 'the impossibility of continuing the present arrangements in respect of the insufficiency of the accommodation for the pauper insane'. However, the most graphic and alarming item is headed 'Housing the Insane' (Journal of Mental Science, January 1897):

'The supplement of the 50th Report of the Commissioners in Lunacy contains the plans of six new asylums providing accommodation for nearly five thousand five hundred insane persons. London County Council at Bexley Heath for 2000, Lancashire for 2000 (chronic) at Winwick, Stafford for 600 at Chedderton, West Sussex for 600 near Chichester and Middlesborough for 250. ... The multiplication of asylums is so rapid, their cost so great, and their import so threatening that the question suggests itself, is there no other way?'

Apparently not. The multiplication continued and, if anything, was accelerated. For example, the Horton Estate in Epsom, Surrey, covering a square mile in area, was designated for 10000 inmates - the largest cluster of mental hospitals in the world. Comprising in chronological order Manor (1899), Horton (1902), St Ebba's (1904), Long Grove (1907) and West Park (1924). In the last case the building was interrupted by the onset of the First World War.

\section{Classification of lunatics}

A survey of inmates in lunatic asylums in Britain at this time would reveal a bizarre hotchpotch of social misfits, some of them suffering from bona fide mental illness, but others with diagnoses less well defined. Perceptive workers in the field who could see the absurdity, or perhaps the inhumanity, of the chaotic situation strongly recommended change (BMJ, February 1895). Mr Jenner-Fust, Local Government Board Inspector, said:

'There can be no doubt that the treatment of imbeciles, especially those of the juvenile class, is totally different from that required for the insane and nothing can be worse for them to be kept in a workhouse where no education of any sort is given. ... [ [He] considered it highly desirable that more adequate provision should be made for this afflicted class, since they are not fitting subjects for lunatic asylums.'

A further example of a more orderly and progressive mind is given by $\mathrm{Dr}$ Yellowlees of Glasgow (Journal of Mental Science, July 1884), who urged:

'Every county or district should have two types of asylums for its pauper insane: one a hospital fully equipped with the best means of treatment, and receiving all new cases, the size not exceeding 300. Another building, erected at half the cost, should be devoted to chronic cases only, and should receive no patients from the cure asylum.'

What has been described thus far is the fate of the pauper lunatic. For the affluent, private care was available in madhouses or licenced houses. Even so, private funding did not guarantee kind and sympathetic care. Unlicensed houses were to be found where, for payment, unscrupulous crooks would house at the cheapest rate people's aged or afflicted relatives. Such a 'Nursing Home or Hell' was visited by two Commissioners in Lunacy (Lancet, 18 October 1902), prompting this feeling of outrage:

'We have no doubt that the Alexandra Nursing House is not the only retreat of the kind where helpless senility falls into a terrible environment to a miserable grave.'

\section{Professional status of psychiatry}

As a professional discipline, psychiatry in Britain in Victorian times - if it existed at all - was in an embryonic state. The 'mad doctors', or 'alienists', who in the main represented psychiatry worked in low-status lunatic asylums and were rarely to be seen or heard outside their institutions. What private practice there was, the 'carriage trade', was the perk of consultant neurologists who, with varying degrees of psychiatric experience, plied their craft from lofty rooms in Harley Street in London or Park Square in Leeds. An outstanding example of this hybrid was a neuropsychiatrist Dr John Hughlings Jackson (1835-1911). He began his medical training at the now defunct York Medical School where one of his teachers was the distinguished asylum alienist, Dr Daniel Hack Tuke (1827-1895) who, most unusually for the time, held an out-patient clinic at the York Dispensary. Jackson attended the clinic and was privileged to visit the West Yorkshire Pauper Asylum, later known as the West Riding Mental Hospital, Wakefield. The Medical Superintendent (from 1866 to 1876) was Dr (later Sir) James Crichton-Browne (1840-1938), 
one of a succession of talented researchers working mainly on brain pathology and histology. His West Riding Asylum Medical Reports, six volumes of which were published by him from 1871 to 1876 , became world-famous, indeed far more prestigious than the Journal of Mental Science, the official journal of the MPA. The regular 'medical conversaziones' held at the asylum flourished under his dynamic management and were attended and addressed by leading neurologists and alienists. More importantly, he was well ahead of his time in inviting students of the Leeds Medical School to visit the asylum for tutorials on the wards, which he often conducted himself. It would not be an exaggeration to claim that the centre of gravity for teaching and research in psychiatry, if it existed at all, had moved from London to Yorkshire, with emphasis on Leeds, Wakefield and York. It would be apropos to mention that a tradition of psychiatric lectureship at Leeds Medical School dates from 1878 and that the first part-time professor of psychiatry in Britain was appointed in 1911, a post filled by Dr Shaw-Bolton, Medical Superintendent of Wakefield Asylum.

Although the primacy of Yorkshire in the academic evolution of psychiatry in Britain is obvious, London cannot be entirely overlooked. For example, John Conolly lectured at Charing Cross Hospital from 1852, J. Fielding Blandford at St George's from 1871 and, after leaving Wakefield, Crichton-Browne lectured at St Mary's from 1881. That this recognition was, at most, grudging is illustrated by the fact that none of these lecturers was appointed physician to the hospital he served. However, an important statement is quoted in the BMJ (23 April 1898 and 30 April 1898) by Dr Henry Rayner (later Superintendent of Hanwell), lecturer on mental diseases at St Thomas's Hospital, London, who instituted an out-patient department for mental diseases at that hospital and advocated similar departments at other public hospitals. In extolling the benefits to the 'poorer classes' (there are repeated illustrations of how class-ridden a society Britain was prior to the First World War), there is a penetrating and long-sighted quotation which shows in a nutshell the Cinderella status of psychiatry in those days $(B M J$, 23 April 1898):

'The bane of alienism in the past has been its isolation from general medicine. So long as the treatment of mental disorders is restricted to separate institutions set apart for the purpose, so long will endure the foolish prejudice that a stigma of disgrace and of horror attaches to it.'

This heartfelt denunciation of this rampant prejudice ends in a plea (BMJ, 30 April 1898):

'We welcome the departure [advent of a psychiatric out-patient clinic] and trust to see a department of mental disorder as invariable and necessary an adjunct to out-patient practice in every general hospital as it is now the department of dermatology or ophthalmology'.

The same radical, if not revolutionary, view is expressed (Lancet, 18 September 1891) by Dr Francis Walmsley who called attention to 'the desirableness of throwing open our asylums for the post-graduate study of insanity'. He says:

'The more the medical practitioner can furnish his mind with information in this direction the less irksome will he find his troubles with lunatics become and the more will he succeed in furthering the proper and efficient working of lunacy legislation on behalf not less of the insane persons themselves than of the community in general.

Despite the hotchpotch of admissions to mental asylums, which the medical staff were powerless to stem, there were voices in the wilderness that insisted in making themselves heard. One example (Lancet, April 1886), protesting with biting wit against the iniquities of the Idiots Bill which failed to distinguish between idiots, imbeciles and lunatics, described it as 'not one whit more intelligible as a means of analysis than the famous synthetical formula, "Caesar and Pompey are alike, especially Pompey", In similar vein (BMJ, 8 October 1887), the Inspector of Lunatic Asylums in Ireland let rip with 'The classes in question - imbeciles, epileptics and idiots - do not require in the majority of cases what must be designated as a genuine asylum treatment'.

An eminently sensible doctor and magistrate, George H. R. Dabbs, writes in a letter to the Lancet (24 November 1900):

'Lunatic asylums are built for the insane: delirium tremens is a passing madness only, and is recoverable from the rigid withdrawal of the exciting cause. ... Among the poor, if the Board of Guardians cannot take such cases in, we as certifying magistrates are constrained to send these poor people to asylums.'

\section{Staffing and training in mental asylums \\ Medical staff}

It must again be stressed that at this time mental asylums were singularly unattractive institutions in which to work and were regarded as something akin to leper colonies. Psychiatry per se was ranked about bottom in the medical curriculum for students; further, its practitioners were given a sideways glance, or were considered with frank suspicion by the medical profession and by and large by the public itself. After all, the lingua franca of psychiatry was not English but German and, to a lesser extent, French. Those internationally famous in the speciality were German or French: examples of the former are Alzheimer (1864-1915), Kraepelin (1856-1926), Nissl (1860-1919), Creuzfeldt (18851964), Binswanger (1852-1929) and Pick (1857-1924, a Czech), and of the latter, Binet (1857-1911), Charcot (1825-1893) and Janet (1859-1947), all world players. The talking treatment (psychoanalysis) of the Freudian variety was in its infancy and had apparently not yet reached our shores.

In Britain, the plight of the medical staff (apart from the lordly medical superintendents) is reflected in the contemporary medical literature. In a letter to the $B M J$ (26 May 1894) the writer deplores the state of the 'Junior MOs', who were 'miserably under-paid and under valued'; and a revealing statement in the Lancet (16 July 1897) points out:

'The proportion of medical officers in asylums is wofully [sic] small, and with the ever-increasing heavy duties of administration little time or energy is left for them for the treatment of their patients.

The same theme is contained in the report of Broadmoor Criminal Lunatic Asylum (Lancet, 11 February 1893), which states, 'There are 539 afflicted people in the asylum for which there is the superintendent himself and his two medical officers'. As a reflection of the low status of assistant medical officers, the most damning indictment of conditions under which they were expected to work and live in asylums under the control of the Metropolitan Asylums Board, particularly Caterham Asylum, is contained in a letter published in the Lancet (20 January 1900). The writer gives lurid details of the humiliating treatment meted out to him and invites any attending applicant to apply first for information to any assistant medical officer employed by the Metropolitan Asylums Board.

As for formal academic teaching in psychiatry available to junior medical officers, reference has been made to available teaching in Leeds and at selected medical schools in London. For the rest, the would-be psychiatrist had the option either to study 
abroad in notable centres such as Vienna, Heidelberg, Berlin or Zurich, or to learn the job at home. To attempt a rather better picture of the academic training available it is necessary to go back to a little before the period now considered.

In 1865 Henry Maudsley (1835-1918) persuaded the University of London to include mental diseases in the curriculum for the final MB examination. In 1885 the General Medical Council added mental diseases as a separate item to the curriculum and demanded that it should be tested. This was usually done by the inclusion of a single token question in the final medicine paper. However, the MPA had stolen a march on Academe, and in 1865 had instituted its own qualification, the Certificate in Psychological Medicine (CPM). There was a prescribed condition of experience after which a written paper had to be passed. A paper (Lancet, 5 January 1889) serves as a dramatic comparison between the papers set then and in today's MRCPsych examinations: the former is essentially a test of how to deal practically with mental patients in given situations. Despite its inadequacies, the beginnings are to be seen of the grudging recognition of psychiatry as an academic discipline.

\section{Medical superintendents}

The hierarchy in mental asylums could best be described not as pyramidal but as linear, so distant was the superintendent from his subordinates. He was an autocrat (benevolent or otherwise) whose princely salary, house (a mini-mansion), retinue of servants, plus ample free provisions and coal, were all evidence of the grandeur in which he and his family lived. The discrepancy between his lifestyle and that of his downtrodden juniors naturally raised protest, or envy. One full page (BMJ, May 1894), signed 'Hopeful', launches a vitriolic attack. 'Hopeful' writes, 'the prevailing asylum spirit is one which makes for the maximum comfort, exaltation and glorification of the superintendent'. Some six years later (Lancet, 9 June 1900) there is a robust counter-attack. The writer says:

that the superintendent should be made a beast of burden and a jack of all trades - a state of things which is not conducive to the best interests of the public asylum service if a medical officer in charge of patients is required to do the work of a steward, an accounts clerk, a farm bailiff, and housekeeper, and a manager of the piggeries.'

\section{Nurses or attendants}

Any attempt at formal training of nurses or (in the case of males) attendants employed in asylums seems to have been a pretty hit-and-miss business. It seemingly depended on the initiative and conscientiousness of individual superintendents. For example, Dr Hitchcock of York (Journal of Mental Science, April 1886) reports:

'During the winter months I have given a course of lectures on elementary anatomy, physiology, and immediate treatment of injuries and accidents etc. to the nurses and attendants of the asylum.'

It was a great success, and his report ends, '.. and if all is well I shall give a similar course next year'.

However, a more formal and regulated effort was made in 1891. Under the title 'The Nursing of the Insane' (BMJ, 9 May 1891) is a report:

'The Council of the Medico-Psychological Association are pressing forward their scheme for organising a system of practical instruction for nurses and attendants in asylums to be followed by examination and the granting of special certificates to those who are successful in passing the required standard.'

The MPA was as good as its word, and gives a resounding rebuff to a Sir W. B. Richardson (Lancet, 3 August 1895). The representative of the MPA writes:

'I cannot allow such a statement to pass unchallenged. For years past the attendants and nurses on the insane have been carefully educated and trained. ... Altogether more than 1000 nurses and attendants possess the certificate which is granted by the Medico-Psychological Association of Great Britain and Ireland.'

It could be added that in 1885 the MPA prepared a handbook (Handbook for the Instruction of Attendants on the Insane, commonly known as The Red Book, most recently in a much larger and comprehensive guise in its ninth edition; Ackner, 1964) 'in the hope of helping attendants of the insane in a due understanding of the work in which they are engaged'. It is a sad irony that in 1885 the Journal of Mental Science, of all journals, saw fit to publish a devastating review of the book. The anonymous critic writes, 'We are not quite sure ourselves whether it is necessary or wise to attempt to convey instructions in physiology etc., to ordinary attendants'.

\section{Diagnoses}

\section{The psychoses}

In his trail-blazing magnum opus, $A$ Dictionary of Psychological Medicine, published in 1892, Daniel Hack Tuke attempts, using his own and other contemporary ideas, a classification of mental diseases, but it is generally accepted as unsatisfactory and has not passed the test of time. Of far greater importance, nosologically speaking, is the German psychiatrist Emil Kraepelin, whose legacy to posterity lies in his epic conclusion that there are only two core mental disorders, manic-depressive illness and schizophrenia. Unfortunately, Kraepelin's dictum post-dates the period now discussed.

The fact that there was no evidence of systematic classification is seen, for example, where Dr F. Magnier maintains that 'apart from idiocy and imbecility...the mental diseases affecting young people are dementia praecox, acute mental confusion, acute delirium, folie périodique, menstrual psychosis, and paranoia' (Lancet, 20 October 1900)-a diagnostic rag-bag if ever there was one. However, the three recognisable frequently diagnosed psychoses are dementia, general paralysis of the insane and the psychoses associated with alcohol misuse. An illustration is seen in the 1899 annual report of the London County Asylum, Claybury, Essex (Lancet, 22 December 1900):

\footnotetext{
'Of insanity associated with senile decay only $10 \%$ were over 60 years of age . . . General Paralysis has been found in $11 \%$ of the male admissions and in nearly $4 \%$ of females. There has been a high percentage of insanity from alcohol, and more than double the number of women than men have been admitted suffering from mania à potu.'
}

Of the psychoses mentioned, the last two (alcohol-related insanity and general paralysis of the insane) were considered the major scourges and deserve further comment. It is difficult at this distance to appreciate the devastating effect of general paralysis of the insane at that time. Six to seven per cent of all mental asylum admissions at the time under review were due to this disease, from which the great majority of patients were doomed to die a wretched, lingering death. Although syphilis was long suspected as the causative culprit, it was not until later in the 20th century that Hideyo Noguchi (1876-1928), a Japanese American, discovered the spirochaete of syphilis in the brains of these patients. Even so, there was no effective treatment until the Nobel laureate Julius Wagner-Jauregg (1857-1940), an Austrian, initiated the first successful treatment with malaria in 1917. His treatment was eventually superseded by the advent of penicillin. 
As to the 'demon drink', references abound, although it is worthy of passing mention that beer was paradoxically a commonplace item of the diet in asylums:

'There was at that time only one county asylum in which the dietary did not include beer' (Journal of Mental Science, vol. 36, 1976).

Nevertheless, the deep concern with inebriety was such that learned societies were founded to study the problem. Such a one was the Society for the Study of Inebriety (BMJ, July 1895), at a meeting of which the director, Dr Rust, 'placed heredity as the chief cause of insanity, and alcoholism the second'.

A legislative solution was attempted: the New Inebriates Act (BMJ, 15 June 1895) was passed in which 'power is given to the High Court and to the county courts to commit to a licensed retreat an habitual drunkard for six months to two years on application of a relative or friend supported by evidence on oath' (the element of compulsion introduced in this Bill must be seen in the context of compulsion introduced in today's new Mental Health Bill). But at least one more enlightened voice was heard advocating treatment not punishment. For instance (BMJ, 1 October 1892) this plea is made: 'Let trial be made of the method of treating them [female inebriates] as diseased individuals in a hospital instead in a prison'.

\section{Treatment}

\section{Alcoholism}

Unfortunately, our predecessors were no more successful in the treatment of alcoholism than we are today, although it seems evident that this particular addiction was more prevalent than it is now. For example, Max Glatt, an acknowledged authority on the subject of alcohol, talks about a severe 'gin epidemic' in the 19th century (Glatt, 1982). Of the treatments in vogue then, there was the simplest, and yet the most difficult of all - 'cold turkey'. At a meeting of the Society for the Study of Inebriety (Lancet, 5 January 1889), Dr James Stewart read a paper on 'Inebriety among the Cultured and Educated Classes'. Among his conclusions is 'there is no danger in the sudden and complete withdrawal of alcohol, no matter how severe'. He adds a rider: 'The physician in charge ought himself to be a total abstainer so that the moral treatment by example might supplement therapeutic remedies'.
More heroic methods were recommended in Russia (Lancet, 3 May 1890). Dr Pombrak writes that he 'found strychnine a very valuable remedy, both in cases of chronic alcoholism and in those cases of dipsomania, not merely curing the attacks, but abolishing the desire for drink'. An even more nerve-tingling method is described by three French researchers, Broca, Salpelier and Thiebault, on the discovery of a so-called anti-alcoholic serum to be called 'antiethylgline'. The method is received by the audience with scepticism and the report of proceedings ends thus: 'It is only right to say that this thirsting serum which does away with any hungering after brandy but preserves the taste for wine was received by the Academy with smiling incredulity'.

\section{The neuroses}

Neurasthenia and hysteria at this time seem to embrace most of those neurotic maladies we recognise today.

Neurasthenia. The term 'neurasthenia', the most popular diagnosis made, was the brainchild of Dr George Miller Beard (1839-1883), an American psychiatrist. It is marked by fatigue, debility, insomnia and 'aches and pains'. A condition as vague and woolly as this invites vague and woolly remedies: for example (BMJ, May 1896), Dr Fleury remarks:

'Neurasthenias are not open to suggestion in the same way as hysterical subjects. Mechanical treatment as by the douche, baths of various temperatures, statical electricity, massage etc. is the most successful. The injection of non-poisonous fluids (Brown-Séquard testicular fluid, etc.) sometimes useful, does not produce its effects by any chemical or specific actions:

Comparably, there is a zany report of a paper (Journal of Mental Science, January 1894) in which a Dr Constantin Paul recommends in the treatment of neurasthenia the 'hypodermic injection of the extract of the grey matter of the brain of sheep'.

Hysteria. Any discussion on this subject must, of necessity, include the influence of suggestion either as a precipitating factor or in the psychotherapeutic process. Of this overlap psychiatrists have been long aware and this has prompted the distinction between bona fide therapists and charlatans, of whom the most famous was Franz Anton Mesmer (1733-1815) who was exposed as a fraud and driven out of Vienna. The blurred differences between one and the other have been responsible for the varying fortunes of hypnotism. The dilemma was excellently portrayed during a 'Discussion on Hypnotism in Dublin' (BMJ, 13 June 1891). Dr F. R. Cruise confessed that 'a year ago he was quite undecided whether the usual statements of the French observers of hypnotism were "either facts, or more audacious falsehoods"'. However, a visit to Nancy and Paris had convinced him that 'hypnotism is a reality, and a great means towards cure, one that can never be crushed by ignorant and baseless criticism'. In the report of the discussion of twelve who joined in, eleven had experienced cases in which hypnotism had been followed by relief and improvement. Only one of those participating in the discussion objected to its employment. It could be added that a decade later at a similar meeting the ratio of yeas and nays might well have been reversed.

The contradictory nature of opinions vis-à-vis the value of hypnotism is evident (BMJ, 9 November 1889). In a meeting in England of Austrian and English psychiatrists, 'Prof. Krafft-Ebing spoke of the future of hypnotism in the treatment with some hope. We can only say that in England the results of trial have been very unsatisfactory'. However, the same warning is heard (Lancet, 7 February 1891) then as today: 'The case is of great importance, as affording a warning that hysteria is not to be diagnosed without the utmost care in excluding every possible form of organic disease'.

There is yet another variety of real or assumed neurosis which is all too familiar in today's litigation-crazy climate. It is raised in the BMJ (April, 1895) under the heading 'The Mental Aspect of Some Traumatic Neurosis' with the comment, 'It was shown how suggestions might play a part in originating new phenomena and prolonging those which have arisen directly from the accident'. A further reference to traumatic neurosis as a trap for the unwary is seen in the Lancet (17 January 1891). The writer warns, 'This [traumatic neurosis] is a convenient term, but like other terms which are convenient it is apt to include far too much'.

\section{The management of 'insanity' in general}

The term 'insanity' is used because, as has already been explained, nosology in psychiatry then was anything but well defined. 
Again, it is necessary to stress that the piein-the-sky dreams of the early reformers had been shattered. The idealised asylums had become grossly overcrowded, undervalued, understaffed and underfunded - in all, not the most propitious climate to engender bright new ideas. It is, therefore, somewhat ironical for Dr George Savage, an eminent and respected Victorian psychiatrist, to echo the aspirations of the reformers (Lancet, 31 October 1891) half a century on. It says:

'There will be few who will not share his [Dr Savage's opinion] as to the efficiency of restful, pleasant surroundings in the treatment of mental disorder as compared with the virtues of "medicine out of the bottle".'

If the pious hopes of the reformers and of Dr Savage had failed, what alternatives were there other than the prayer that the remissions seen not infrequently as the natural history of mental diseases would come to their rescue? There were alternatives, but they were merely palliatives or for the treatment of symptoms. For example, how to cope with motor overactivity, or frank violence, symptoms as common then as now? There was restraint - or 'non-restraint', or call it 'moral treatment' if preferred, the code of practice first advocated and practised by Pinel at the Salpêtrière in revolutionary France, and later in England by the Tukes of York. This highly desirable code was all too infrequently observed in England's asylums: straitjackets, manacles and leg irons had not yet been confined to psychiatric museums, and padded cells were commonplace well into the 20th century.

As for the 'chemical cosh', bromide, paraldehyde and chloral hydrate, chemically contrived in the mid-19th century, were ubiquitous. It is relevant to quote (Lancet, 23 March 1889) a reference to a paper by Dr Watson on the use of sulphonal which is described as a useful and harmless drug, although Dr Yellowlees added that he had seen giddiness produced by it. As a rider it can be added that both paraldehyde and chloral hydrate could become drugs of addiction and they are, therefore, not as innocuous as described. The same warnings apply to the barbiturates, an increasingly popular drug in psychiatry from 1903 onwards.

There were other methods of treatment, some of them idiosyncratic but harmless, and others hair-raisingly dangerous. Of the first variety is 'cycling for the insane' (Journal of Mental Science, July 1890), which its advocate says, 'Rushing through the air at 12 miles an hour, will lift the gloomiest thoughts from the mind, if only for a short period'. Music is also proposed as a remedy (Lancet, 29 April 1891), of which the writer says with justice, 'the same attraction of melody has been credited in our own days with curative property'. Of the second variety of treatment, an example is seen in the Lancet (3 February 1894) entitled 'Hypodermic Injection of Brain Extract in Mental Diseases' (the source of the brain extract is not identified). The author's results are, not surprisingly, very modest: of six cases experimented with, one was rated improved and five were negative.

There are two examples concerning the use of drugs of addiction which are well worthy of mention if only because of their relevance in today's debates. The first (BMJ, 4 July 1890) is headed 'Therapeutics of Indian Hemp'. The writer mentions his cases in which the drug proves beneficial, including anxiety, melancholia, mania, chorea (where arsenic fails), migraine and gastrodynia. He ends, 'Its value is well known to asylum physicians, but it does not appear to have obtained the confidence of the profession generally'.

The second (BMJ, 18 March 1893) is entitled 'The Effects of Opium Smoking'. The author, M. L. Baret, a French naval surgeon, concludes: 'Opium smoked occasionally ... acts as a general tonic, and an economising agent to alcohol and to coca. As to its mental action, it is the most powerful tonic that exists'.

\section{Doctors v. lawyers}

The relationship between members of the medical and legal professions has fluctuated over the years as does, say, the relationship between England and France - a mixture of hate and love with more emphasis on the former than the latter.

At the time considered, the relationship had reached its nadir: the altercations occurred most frequently during crossexamination by counsel and medical witness ('forensic psychiatrists' as a separate entity did not exist: Dr L. Forbes Winslow and Dr Clifford Albutt, both distinguished physicians, for example, were frequently engaged as witnesses). An alternative source of rudery emanated from the learned judge himself (Journal of Mental Science, April 1889):

'Mr Justice Field in addition to treating the medical witness with studious rudeness, refused to receive their opinion as to the sanity of the prisoner. "He could no more dive into a man's state of mind than I can", was his final lacerating riposte.'

A further case is not related to rudeness but to diametrically opposed opinions given by two judges in comparable cases. In a letter to the Lancet (22 February 1888) Dr Forbes Winslow relates that in a case at Maidstone, 'The medical men examined were asked whether in their opinion he (the accused) was of unsound mind. The answer was in the affirmative'. Dr Winslow goes on to say that he had gone down to Leeds to give evidence in another case of similar description and found that $\mathrm{Mr}$ Justice Day had ruled exactly opposite. His intemperate rebuff was framed thus:

'Experts are not to be asked questions which the jury are sworn to try. You may ask matters of fact as to what he saw or heard, but you must not ask him whether he is sane or not.'

A rallying call in support of the medical witnesses is made in the Lancet (18 February 1893):

"We are strongly of the opinion that cases where the existence of insanity is alleged ought never be decided without medical evidence.

However, the most vitriolic exposé of the deteriorated relationship between the two professions is seen in a leader (Lancet, 2 April 1904) headed 'The Attitude of the Legal Profession towards the Medical Profession': 'In a letter [Lancet, 27 February 1904] Dr E.
Magennis writing of the conduct of barristers in
Ireland, deplored the disappearance of the
courteous treatment of the medical witness
which once characterised cross-examination
but which at the same time did not prevent the
most vigorous investigation of the facts, and he
drew attention to the unwarranted imperti-
nence, frequently amounting to positive insult,
which appears to arise from the assumption that
the medical witness must not only be prejudiced
but ready to give perjured evidence on behalf of
the party employing him.'

The leader goes on, 'such discourteous treatment of the medical witness is not confined to the Irish courts but is comparatively rare in England', and ends, 'all such witnesses are entitled by members of the bar with the respect due from one learned profession to another'.

\section{The Medico-Psychological Association}

The forerunner of the MPA, the Association of Medical Officers of Asylums and Hospitals for the Insane, the brain-child of Samuel Hitch, was initially formed so that 
'medical gentlemen connected with lunatic asylums should be better known to each other'. Those invited to attend the preliminary meeting in 1841 were all medical superintendents, the grands seigneurs of British psychiatry at the time. In essence it was a cosy gentlemen's dining club and as such it continued with distinct fluctuations in its fortunes (in 1855 the membership was a mere 121), but as a result of the proliferation of new mental asylums during the second half of the century the membership had risen in 1894 (the beginning of the period concerned in this paper) to 523. Even so, its annual general meeting, held on 11 May 1899, attracted approximately 50 members; however, these included the crème de la crème of the psychiatric establishment such as it was, for example, Gardiner Hill, Helen Boyle, R. Langdon Down, C. H. Bond, Ernest Jones, J. R. Lord, W. H. R. Rivers and F. W. Mott. The attendance at annual general meetings remained small, probably owing to the difficulty of any but the superintendents attending; juniors were often isolated and in sole control of their asylum. (A possible further explanation of the poor attendance at meetings is the somewhat esoteric nature of the papers read. For example (Lancet, 5 May 1900): 'Dr W. J. Koenig will read a paper in English on "Pupillary Anomalies in Paralysis and Non-paralysed Idiot Children and Non-paralysed Idiots and their Relation to Hereditary Syphilis"'.) Politically speaking, the Association was an impotent body with little influence on legislation affecting the control of asylums and the welfare of patients committed to them. (In any event, if Parliament had deigned to seek advice, it would have been more likely to approach the Royal College of Physicians than the MPA, a much junior partner in the association of medical colleges or corporate bodies.) Of particular importance in this context is the protest (Lancet, 10 July 1897) to the Lunacy Act 1890 and its amendments. The protester writes:

HENRY R. ROLLIN, MD, FRCP, FRCPsych, Emeritus Consultant Psychiatrist, Horton Hospital, I0I College Road, Epsom KTI7 4HY, UK

(First received 5 February 2003, final revision 22 May 2003, accepted I3 June 2003)

'The case is potent and obvious. The Lord Chancellor is at the head of the lunacy system. Hence the anomaly of the Lunatic Commission, entrusted with the supervision of the treatment of insanity throughout the kingdom, being mainly composed of barristers. This ridiculous state of affairs is about comparable to what would obtain if the Lord Chancellor was supreme over the Admiralty when, no doubt, we should see an equal number of barristers and naval officers commanding our fleets, while our captains of ships would spend all their time in forms and correspondence in regard on why Jack had had his grog stopped.'

\section{EPILOGUE}

\section{Two tears for psychiatry}

To parody the late Roy Porter in this final section is not to deride him: on the contrary, this is an opportunity to praise him and honour his memory. But why swap his 'cheers' for my 'tears'? The reason is simple. The composite picture of psychiatry in Britain at the end of the Victorian era and a little beyond is chiefly one of unremitting gloom. To quote Porter, but now verbatim: he refers to the fertile soil for psychiatry on the continent of Europe and in North America around 1900 and contrasts the situation in Britain, concluding that here psychiatry one hundred years ago 'might be seen as a badland where for the most part, psychiatry remained something of a retarded and stunted growth and the public tended to be at least lukewarm towards the psychiatries old and new alike' (Porter, 1998). I agree wholeheartedly with Roy Porter's adverse comment. This, together with the massive evidence emerging from the foregoing, describes in graphic detail the parlous condition of British psychiatry at one particular period in its history. Nevertheless, in a perverse way, its badness serves a useful purpose - it affords a baseline from which one can measure the quantum leap psychiatry has taken during the 20th century.

\section{DECLARATION OF INTEREST}

None.

\section{ACKNOWLEDGEMENTS}

I am indebted as I have been for more decades than I (or she) would care to remember to Ms Diana Shields for her secretarial services, and to my proofreader-in-chief, my wife, Maria.

\section{REFERENCES}

Ackner, B. (ed.) (1964) Handbook for Psychiatric Nurses (9th edn). London: Baillière, Tindall \& Cox.

Arlidge, J. (1859) On the State of Lunacy and the Legal Provision for the Insane. London: Churchill.

Glatt, M. (1982) Alcoholism. Sevenoaks: Hodder \& Stoughton

Hunter, R. \& MacAlpine, I. (1974) Psychiatry for the Poor 1851. Colney Hatch Asylum - Friern Hospital 1973; A Medical and Social History. Folkestone: Dawsons.

Porter, R. (1998) Two cheers for psychiatry! The social history of mental disorder in twentieth century Britain. In 150 Years of British Psychiatry, vol. 2. The Aftermath (eds H. Freeman \& G. Berrios), pp. 383-406. London: Athlone Press.

Scull, A. (1982) Museums of Madness. The Social Organisation of Insanity in Nineteenth Century England. Harmondsworth: Penguin Education.

- (1989) Lord Shaftesbury, Diaries, 5 September 185I, quoted as a heading to Chapter I. In Social Order/Mental Disorder. London: Routledge. 